\title{
COVID 19-A Qualitative Review for the Reorganization of Human Living Environments
}

\author{
Ilenia Pierantoni ${ }^{1, *(1)}$, Mariano Pierantozzi ${ }^{2}\left(\mathbb{D}\right.$ and Massimo Sargolini ${ }^{3}$ (i) \\ 1 Post-doc Research Fellow, School of Architecture and Design, University of Camerino, 62032 Camerino, Italy \\ 2 Research Fellow, Department of Architecture, University of G. d'Annunzio Chieti and Pescara, \\ 66100 Chieti, Italy; mariano.pierantozzi@unich.it \\ 3 Full Professor of Town and Regional Planning, School of Architecture and Design, University of Camerino, \\ 62032 Camerino, Italy; massimo.sargolini@unicam.it \\ * Correspondence: ilenia.pierantoni@unicam.it
}

Received: 16 June 2020; Accepted: 7 August 2020; Published: 12 August 2020

check for updates

\begin{abstract}
The COVID-19 pandemic is changing people's habits and behaviors and will reshape city layout and management. Among the different areas of research to be explored, the paper outlines first inputs to use the COVID-19 health crisis as a "window of opportunity" to trigger a sustainable transition of urban living environments, through actions to reshape and territorial organization after COVID-19 and in preparation for future health. Before having a vaccine or medications that ensure a non-lethal disease course, there will be a phase of responsibility and coexistence with the virus. It will be a period whose duration experts are still unable to quantify. What changes in the city organization, behaviors and uses of spaces will we observe in the living environments? Will this lead to a sustainability transition? The paper proposes a qualitative review to investigate how the droplet might travel through the air and how COVID-19 has spread in different urban contexts to outline a comprehensive reflection on the future of the city and strategies for more resilient communities and territories. To achieve this goal, the paper proposes the need of a comparison between skills related to physics aspects, such as fluid dynamics (to assess how droplets spread) and skills related to architectural, urban and territorial design (to evaluate the conditions of indoor and outdoor living environments).
\end{abstract}

Keywords: COVID-19; urban morphology; sustainability transition; risk prevention; inland attractiveness

\section{Introduction}

Coronaviruses were classified in the mid-1960s and are recognized to infect some animals and also humans. They are a large family of viruses known to cause diseases ranging from the common cold to more critical diseases such as Severe Acute Respiratory Syndrome (SARS) or Middle Eastern Respiratory Syndrome (MERS). In December 2019, in Wuhan, China, a new virus belonging to this family, called SARS-CoV-2, was isolated. Since the viral sequence of this new Coronavirus has a substantial similarity [1] compared to the virus that caused the SARS pandemic in 2002/2003, the two viruses are considered remarkably similar.

The dramatic health crisis that the entire planet is going through has produced an impressive number of victims, an unprecedented economic crisis and will bring permanent changes in social behavior. At times, the effects on the urban and infrastructural structure seem to be underestimated, which will inevitably have to be rethought and reshaped right after the lockdown in a medium-long term perspective, making increasingly urgent to accelerate the "transition to sustainability." Strategies and actions to put in place a sustainability transition, in coherence with the European Green New Deal, 
are today more than ever urgent to prevent risks, increase resilience and improve the quality of life in urban areas.

In this sense, the natural biological disaster we are facing is only the latest in a series of critical signals on the health of the planet that we have received over the last quarter of a century. From the United Nations Conference on the Human Environment [2] to the World Conservation Strategy [3]; from the World Commission on Environment and Development and the Bruntland Report [4] to the United Nations Conference on Environment and Development in Rio [5], there is a growing debate on the need to care for the future of the planet. We should interpret this crisis as a further piece of the complex puzzle, which is the progressive loss of balance of our planet. Interdisciplinary research actions are necessary to understand this moment and to develop strategies to increase the resilience of communities and territories. In this framework, paragraphs "2. How the droplet might travel through the air" and "3. How COVID-19 has spread in different urban contexts," present a qualitative review on how Coronavirus spread in the various urban contexts, highlighting the close relationship between the virus propagation and the specific local conditions (i.e., local microclimate and air pollution). What emerges is that that the organization of urban spaces, population density, infrastructural networks, socio-economic conditions, and, more generally, the different preparedness of society to natural events are all factors with strong linkages one to another. Some territorial and urban structures with specific combinations of the factors mentioned above have shown to be likely more affected by the diffusion of the virus. Other particular aspects regard the capacity to communicate and implement emergency response but also the availability, quality and accessibility of care facilities and essential equipment.

Paragraph "4. First inputs to use the COVID-19 health crisis as a "window of opportunity" to trigger a sustainable transition of urban living environments," foresees a selection of first primary actions to reduce the spread of the virus. These actions are organized into two main themes-(1) detailed indications to contain the droplet at the local scale making use of green solutions; (2) strategic scenarios at large scale to interlink the city to the context (i.e., through polycentric organization of primary services; sustainable mobility, green networks). The proposed actions, framed in the Sustainable Development Goals [6] are aimed both at timely mitigating the spread of the droplet and at rethinking cities with their context. In a transition challenge towards sustainability, this dual complex multi-scalar and multi-actoral approach is necessary to counteract the spread of the virus on a local scale, while limiting the factors amplifying its effects on people at the broader scale [7].

The proposed methodology follows the idea that complex problems require complex solutions and not only simple statements like those regarding the migration of population from cities to less populated inland areas because of their new attractiveness related to the distance from the crowded, polluted and contaminated cities. As a matter of fact, the debate among planners, geographers, economists is now dealing with the "end of cities" scenarios to prevent pandemics and mitigate the risk of future health crises [7]. In this sense, some authors propose a counter-exodus from the city to the rediscovery of small isolated cities, towns and villages located in rural and mountainous areas, inland areas, many of which are now abandoned due to the progressive depopulation and negative socio-economic trends of the last decades. This emotional tension will bring changes in the living organization in the short-term, due to the attractiveness of more isolated and marginal inland areas, where nature prevails and the virus had less impact. However, the progressive depopulation and loss of basic services that characterize inland areas make them unable to offer a consistent quality of life in the long-term perspective.

The qualitative review proposed in this paper also outlines a first understanding of where disease outbreaks mostly occur; how they relate to the physical, spatial, economic, social and ecological characteristics of places; and what components of the urban living environments and can play a role in stemming potential future outbreaks. The attempt is to outline a research path based on inputs from the actual debate on the COVID-19 health crisis to define new future scenarios about: 
1. how to reshape urban contexts and their management to prevent risks and ensure a safer and better urban life in cities, which are the primary places for living and producing;

2. how to rethink relations between cities and their territorial context, often rich in natural and cultural resources but often affected by depopulation and lack of essential services.

This may be an opportunity to effectively respond to natural biological disasters such as COVID-19 and others that may happen in the future but also to develop policies to rethink cities and their contexts, considering that the response to the current health crisis involves the reorganization of living spaces both inside and outside cities, which have so far been underestimated in the development of solutions for well-being, quality of life and safety. This proposition requires systematic visions that are able to discover different fields of study, favoring interactions between:

- $\quad$ expertise in the medical and health field, as well as technical physics and fluid-dynamic engineering, to analyze the spread of the virus in different types of indoor and outdoor environments, in different social contexts and land uses, trying to understand the ways, times and factors that can amplify or reduce the virus propagation;

- expertise in geography, urban planning and socio-economic fields, to define strategies to reshape cities and to consider the real potential of small cities, towns and inland areas, in the light of territorial post-COVID reorganization, highlighting preventive solutions for public spaces and services that may contribute to increasing the quality and safety of life and a sustainability transition.

\section{How the Droplet Might Travel through the Air}

In this paragraph, we describe how the spread of the virus can vary considerably between indoor and outdoor scenarios and how some fluid dynamic considerations can be an input to a rethinking of the geometry of the city that will be described in the following paragraphs.

The droplets naturally produced by the human being in his normal behavior of breathing, talking, coughing and sneezing are composed of different types of cells, physiological electrolytes present in saliva and also potential infectious agents such as fungi, bacteria and finally viruses. The biggest controversy among scientists over the transmission of the COVID-19 is the size of the droplets [8] that would allow the virus to spread. In fact, there is a big distinction between droplets with a diameter greater than 5 micrometers and those with a smaller diameter. The first commonly called droplets allow the virus to spread below two meters, the infamous 6 feet, which in countries of non-Anglo-Saxon origin are estimated at $1.80 \mathrm{~m}$. The other type called droplet nuclei that are commonly called aerosols, however, which would allow the virus to spread well beyond the distance mentioned above. This distinction is very old and is first traced back to Carl Flügge [9] who, in 1897, demonstrated how transmission by air was caused by fairly large droplets and then by William F. Well [10] who in the study of tuberculosis distinguished contagion by large and small droplets. More recent studies [11-13] have attempted to understand the size of the droplets on saliva as well as their number to try to predict infectivity and the distance of fall.

All these studies and also other more recent studies $[13,14]$ show great variability of components and many factors that can influence propagation phenomena such as the thermophysical variables of the surrounding air (e.g., viscosity), the speed of the air itself and its humidity. This marked distinction now leads to an even more pronounced dichotomy [15] among scientist who attempts to predict the spread of COVID-19 in closed or open spaces based on the type of droplets carrying the virus.

Thanks to studies by Buorouiba et al. $[8,16]$, it is now clear that both sneezing and coughing cannot only be reduced as compounds of large and small droplets following a ballistic trajectory. However, these exhalations are a turbulent multiphase gaseous composition that can also be studied from a fluid dynamic point of view with complex mathematical models. This greatly complicates the simple reduction to two types of distances of 2 or $6 \mathrm{~m}$ but also considerably extends the range of distance at which individuals have to stand for their safety. These observations lead us to reconsider outdoor 
safety with greater awareness and taking into account every aspect of the most advanced research in this field.

The more and less recent studies on the diffusion of the Coronavirus in outdoor environments take into account the intuition of the turbulent gas cloud by investigating the possibilities of virus diffusion in outdoor environments. Already in the previous SARS coronavirus epidemic, there was evidence [17] of air-borne virus transmission. In a preprint [18], Yuan Liu et al. studied 35 aerosol samples of three different types (total suspended particle, aerosol with dimensional separation and deposition) collected in various indoor environments of Wuhan and its surroundings. The conclusion they come to is that even small droplets of aerosols can cause COVID-19 infections but they confirm that confinement and non-recirculation of air amplify the danger. In fact, for example, one of the places with the highest concentration of bacterial load was the toilet due to surface contamination and non-recirculation of the air. Liu et al., in their study, which is one of the first from Wuhan, conclude that the deposition of aerosol charged with the virus may play a role in surface contamination and subsequent contact by susceptible people, resulting in human infection. In addition, in their reconnaissance, they conclude that in public places outside hospitals, most sites have undetectable or very low concentrations of SARS-CoV-2 aerosols. The only exception was a crowd collection site about $1 \mathrm{~m}$ from the entrance of a department store with frequently passing customers and the other site near Renmin Hospital where clinics and passengers passed. They conclude that it is realistic that asymptomatic carriers of COVID-19 in the crowd may have contributed as a source of virus-laden aerosols during the sampling period. Finally, they state that the results of their study show that the risk in public places is overall low while stressing the need to avoid large crowds. In addition, the use of personal protective equipment, such as masks also in public places or during transport, may reduce exposure and transmission of aerosol.

Moreover, in this research of indoor transmission [19], the authors study the causes of virus transmission for 318 outbreaks of SARS-CoV-2 in 120 cities in China. Although their study is focused on indoor environments, in the considerations, authors confirm that virus transmission is a phenomenon that occurs predominantly in indoor environments censusing only one case of an infected man outside after having had an outdoor conversation with an infected individual. However, we would like to point out once again that not all scientists agree on this point in admitting this type of spread of the virus by aerosols. Within this framework, the possibility of spreading the virus through the particles that cause pollution is part of this framework.

Preliminary research of some Italian authors [20] has highlighted the presence of Coronavirus inside the smog particles. This would lead to the possibility of increasing the number of people who may be infected by the virus. In these studies, smog samples were taken in the industrial area of Bergamo (Northern Italy), where the presence of the virus gene was detected. Although this thesis has not yet been reviewed, however, many scholars pay particular attention to this hypothesis, which requires more reliable studies. In this other work [21], the possible relationship between the spread of the virus and pollution is highlighted, pointing out how the pollution aspect cannot be forgotten in the study of pandemic spread.

All the considerations that we have made so far make us understand how the spread of the virus varies considerably between an indoor and an outdoor scenario. The studies examined provide precise details of how few cases of infections occur outdoors and this leads us to rethink the outdoor spaces as well.

For example, the increased use of barriers between people can have a two-fold effect-On the one hand, reducing the spread of the virus even in open spaces and, on the other hand, encouraging physical distancing and more virtuous behavior by users of urban spaces.

Moreover, given the correlation between viruses and pollution, both the formation of green spaces and new plantings in urban environments and the design of less energy-intensive cities can help. This means to rethink the entire urban ecosystem to limit the phenomenon of pollution within cities, both large and small. In the next paragraph, we will analyze the relationship between urban living 
conditions (i.e., the form of the city, the presence of services and human behavior) and the spread of the virus.

\section{How COVID-19 Has Spread in Different Urban Contexts}

Disease shapes cities; on the other hand, cities also play a central role in preparing for, mitigating and adapting to pandemics [22]. Some of the most iconic developments in urban planning and management, such as Napoli's cholera outbreaks, London's Metropolitan Board of Works and mid-19th century sanitation systems, developed in response to public health crises [23]. Now, COVID-19 is joining a long list of infectious diseases, like the Spanish flu of 1918 or the Ebola Virus Disease in West Africa in 2014, likely to leave enduring marks on urban spaces. Right after the last Ebola epidemic, scientists stated that understanding the spatial, temporal distribution of new infectious diseases is among the most critical and challenging tasks for the future [24-27]. Furthermore, the intersection of urban planning and design and public health is an increasingly relevant field of research [28-30].

Emerging infectious disease has much to do with how and where people live. The most recent global disease outbreaks have originated in China and Africa, which are also amongst the most rapidly urbanizing [31] and highly populated regions. The ongoing Coronavirus is an example of the close relationships between urban development and the diffusion of infectious diseases. Different urban and territorial morphologies characterize European regions. These differential characteristics are even more visible in the case of Italy, where population distribution can vary from metropolitan cities to medium-sized cities, small villages and scattered hamlets in mountainous and inland areas. The spread of COVID-19 in different urban contexts of Europe has been significantly heterogeneous in speed, reach and mortality, not only from country to country but also in different regions of the same country, as the Italian case. However, some common factors may be highlighted. According to Ferrari et al. [32], the main possible explanation is given by the delay between the onset of the epidemic, the first diagnosis and the kick-off of containment measures. Other reasons are on region-specific variables, such as population density and mean age, societal structure and behaviors. Other factors relate to the adopted policies for containment and testing, in particular for what concerns the fraction of infectious individuals that do not show symptoms (asymptomatic).

In theory, the virus contaminates humans in the same way but there are some aspects, like the timing of containment and the specific population characteristics, particularly the aging population, that has made the virus more deadly. Cities with a high concentration of urban poor and deep inequalities are potentially more vulnerable than those that are better resourced, less crowded and more inclusive.

Furthermore, impacts of the virus may vary significantly depending on the specific characteristics of the urban context, such as the distribution of urban density, land use patterns, population behaviors (i.e., work-home transfers, social and gathering activities), mobility and infrastructure organization, economic dynamics and governance [33,34].

According to Cliff et al. [35], epidemic diseases spread in three main ways-the hierarchical model (between large cities), the local model (through neighborhoods) and the "jump" model (along transport routes). As Bourdin and Nadou [36] stated, this was particularly true with HIV/AIDS and SARS, which spread by jumping from point to point. For this reason, the notion of proximity is defined as connectivity between different locations of a network. COVID-19 rapidly spread in this way, from limited 'hotspots' to broader areas, sometimes a long way away. The "jump" model shows that mobility and transports are a risk factor if no precautions are taken. The rules of diffusion change in a way that a place strongly connected to the starting point of the epidemic (so not necessarily close to it) has a significant probability of being affected before a poorly connected place. The places affected simultaneously by the same starting point of the epidemic have a similar degree of connection, regardless of the real distance in kilometers. This is, even more, the case of regions with a wide alternation of densely and sparsely populated areas and urban, suburban and rural areas [33,37]. COVID-19 first spread in Wuhan, one of the largest Chinese cities and a major transportation hub 
with national and international connections. A report of the WHO [38] refers that given Wuhan's transport hub status and population movement during the Chinese New Year, outbreaks quickly spread throughout the country and were mainly concentrated in cities with the highest volume of traffic with Wuhan. Urban and peri-urban infrastructures are the base of urban mobility and circulation and socio-natural metabolisms [34]; infrastructures are also those establishing structural relations between different places on a global scale. For this reason, COVID-19 has shown that infrastructures can facilitate the transmission and make cities and peri-urban areas more vulnerable.

Analyzing the contamination within cities, peri-urban areas and rural areas shows how much population density affects different contamination dynamics. Numerous researchers have noted that population density, which is highest in cities, strongly influences the likelihood of a disease outbreak $[31,39,40]$. New York City in the USA, Mumbai in India and London in the UK are all considered dense cities in their respective countries and are also hotspots for COVID-19. But, on the other hand, there are the cases of Singapore, Seoul, Hong Kong and northern Italian regions on Veneto and Piemonte, where dense cities have outperformed lesser-populated places [41]. The World Bank conducted a study on COVID-19 diffusion in urban contexts with different population density, collecting data for 284 Chinese cities based on the number of confirmed Coronavirus cases per 10,000 people [42]. The study showed that cities with high population densities had far fewer confirmed cases per 10,000 people. The authors report that the reasons may be that with economies of scale, cities often meet a certain threshold of population density to offer higher-grade facilities and services to citizens [43]. Therefore, they develop better-coping strategies for the pandemic, leading to lower infection rates. Authors also observed that while major urban areas are indeed key jumping points for an epidemic outbreak to go global, COVID-19 also drove a distinctly broader impact on what is urban. The cases of the German or Italian outbreaks of COVID-19, with links between a periurban Wuhan car manufacturer and a factory in suburban Bavaria [44] or the small towns of Codogno $(60 \mathrm{~km}$ from Milan) or Vo' Euganeo (30 km from Padua and 85 from Venice) bring attention to the larger urban realities around and between big cities. According to Acuto [45], the epidemic challenge comes as much from the cores of the world economy than it does, as Roger Keil and others clearly [46] noted, "from the edges" of cities, which have been to date largely overlooked.

In Europe, observing Figure 1, there is an extraordinary geographical coincidence between COVID-19 contamination and areas covered by major urban and peri-urban areas, with important productive and commercial dynamics. On the other hand, there is also a coincidence between regions with a lower diffusion of the virus and peripheral inland and mountainous ones. In Italy, for example, this is particularly evident in the Alps and the Apennines, which are rich in biodiversity, natural parks and protected areas and often classified as "inland areas" according to the Italian National Strategy of Inland Areas [47,48]. In recent times, due to COVID-19 pandemic, these areas have revealed increasing attractiveness for their natural capital and remoteness from large cities and pandemic outbreaks. 


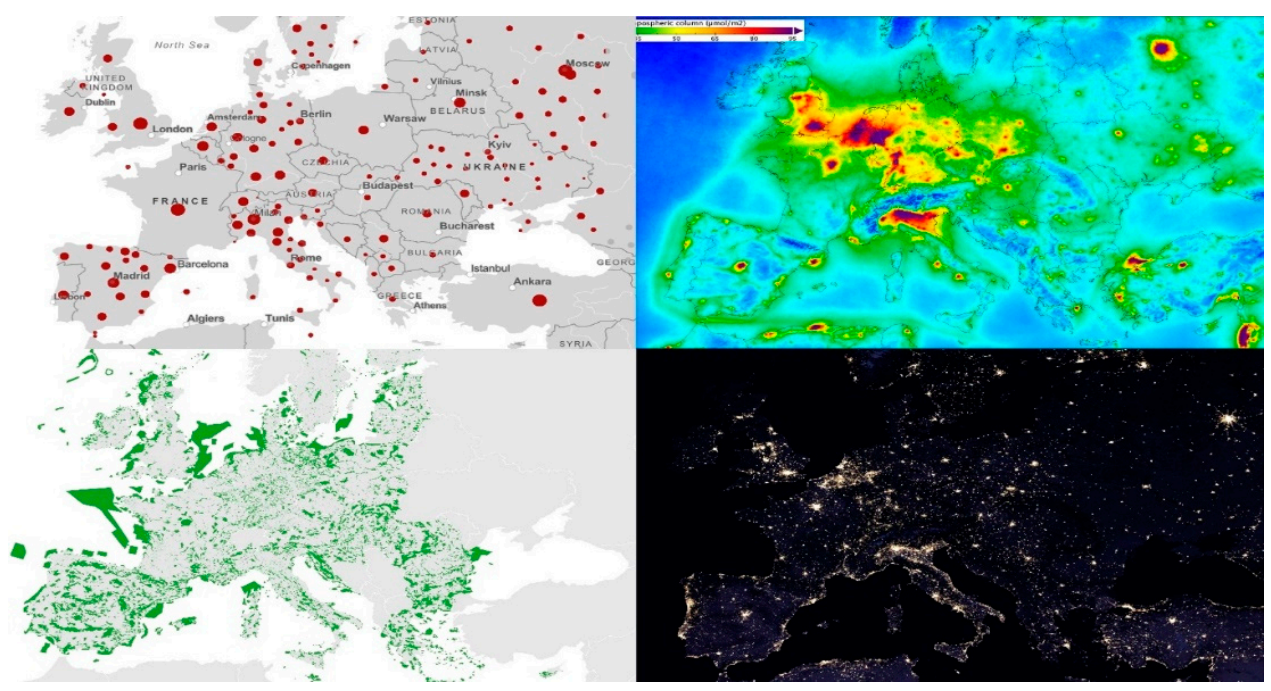

Figure 1. The figure presents a double territorial interpretation: geographical coincidence between major urban and peri-urban areas, pollution distribution and COVID-19 contamination; geographical coincidence between natural areas rich in biodiversity, less pollution distribution and less COVID-19 contamination (a reworking of Ilenia Pierantoni on the base of: top, left: EU map of COVID-19 Cumulative confirmed cases-Source: processing Ilenia Pierantoni on COVID-19 Dashboard by the Center for Systems Science and Engineering (CSSE) at Johns Hopkins University (JHU); top, right: Nitrogen dioxide map distribution, Source: European Environmental Agency; below, left: Distribution of the Natura 2000 protected areas network in Europe, Source: processing Ilenia Pierantoni on EEA database. below, right: European Night Lights Maps, “Earth at night, "Source: NASA Earth Observatory images by Joshua Stevens, using Suomi NPP VIIRS data from Miguel Román, NASA's Goddard Space Flight Center).

\section{First Inputs to Use the COVID-19 Health Crisis as a "Window of Opportunity" to Trigger a Sustainable Transition of Urban Living Environments}

COVID-19 health crisis demonstrates how our global system is organized around global cities and how, through international connections, epidemics can go global. The pandemic has also highlighted the unpreparedness of cities and governments at different levels to deal with specific natural hazards, such as the biological one COVID-19. As Taleb et al. (2020) [49] stated, "the pandemic is not a black swan but a portent of a more fragile global system;" there is the need for solutions not only to contrast COVID-19 but also to make cities more "anti-fragile," efficient and resilient.

Unpreparedness was mostly observed at the emergency-management level. Besides, issues sometimes underestimated in the past, such as urban air pollution and care of green urban and peri-urban areas, revealed to be crucial to contrast pandemics and must now be taken into account for mitigating and preparing to epidemic outbreaks and other risks. In fact, according to Muggah and Katz (2020) [22], "the extent of a city's preparedness depends on its capacity to prevent, detect, respond and care for people. The ability to communicate and implement emergency response plans is also essential, as is the availability, quality and accessibility of hospitals, clinics, care facilities and essential equipment."

Unpreparedness is also evident in the medium- and long-term policies for the city. The pandemic made clear the urgency for a transition to sustainability, repeatedly evoked in recent decades but mostly never put into planning action [49]. Today seems clear to all that if we had greener and less polluted cities, with a better organization of the transport system and the use of public services, with strong habits in smart-working, we would have had more resilient cities and a stronger ability to react to "the external disturbance" caused by the spread of the virus. If we had made these choices in due course, we would have taken an essential step to the transition to sustainability. This transition towards new balances on the planet must take into account the reorganization of urban and peri-urban areas and the relationship these have with less populated areas, therefore with the territorial context [50]. 
The challenge is to deepen and put into action the visionary idea of F.L. Olmsted [51], launched in the USA in the mid-nineteenth century, who grasped the value of green open spaces in urban areas for the health and quality of life of city inhabitants. Furthermore, it is also essential to research the relationships between biodiversity preservation and the quality of the city $[49,50,52]$. The institutional philosophy of protected areas and the recent evolution of its basic concepts in the last decades must be re-taken. Natural Protected areas can become the first field of experimentation for the metaphor of a new relationship between man and the environment [53] for a higher quality of life and human health [52]. But in order to achieve this goal, the starting point is to shift the focus to the quality of life of the inhabitants and from the closer vision on the cities to a wider one that includes the relationship between cities and natural and semi-natural context.

With this framework, it becomes an obligation to consider this particular historical moment as an opportunity to trigger sustainable changes and transition in the management of living spaces both in big cities, which are the core of global dynamics and the real engine of social and economic change $[54,55]$ and in the small and more isolated ones, often rich in biodiversity and landscape values but in need of essential primary services. In this sense, the rebirth after the natural biological disaster COVID-19 is the case of a "post-disaster window of opportunity" [56-59], in which the disaster is a catalyst for change and the reconstruction process represents a favorable moment to introduce and consolidate novelties in policy $[59,60]$ to improve people's safety and quality of life. Acting to reduce the community's fragility and vulnerability through the care of well-being and health means working to improve living environments and, therefore, also reshape users' behavior. In this way, rebirth can be an opportunity to introduce targeted government actions to accelerate strategies towards sustainability $[61,62]$ through careful and properly calibrated measures at two different levels of urban and territorial transformation:

\section{The Level of Urban Space Design:}

- increase green in living environments, such as green spaces or vegetative barriers as a way to improve the relationship between nature and city. Green solutions may also contribute to multiple purposes, such as mitigating climate change, preventing heat-island effects, provide more public spaces (for outdoor recreation), even increasing the security of the open space acting as barriers to prevent the transmission of the virus by air or providing a milder way of social distancing;

- promote the shift toward smart solutions in city management and people's behaviors. Smart cities are living environments where physical and digital infrastructure co-exist with human capital and social capital toward improving citizens' quality of life. In particular, the overcoming of the digital divide through increasing digital and telecommunications equipment both in large and small cities becomes a primary design action to encourage new behaviors and energy savings;

- favor the creation of urban energy efficiency districts, with heat and cooling production plants using alternative energy sources (solar, geothermal, wind) and district heating networks;

\section{The Level of Relations between Cities and the Territorial Context:}

- rethink the concept of urban density and the dense city-polycentric model relationship that may offer well-being opportunities. This may be possible by putting it on cities urban agenda the four principles the principles of the "hyper-proximity cities" concept-proximity, diversity, density and ubiquity [63]. The aim is to shift to a more polycentric organization of living environments and prioritize multimodal transportation and human beings rather than car-centric design. A new vision of cities and density, where travel times are reduced in favor of people well-being;

- $\quad$ rethink the distribution of essential services, moving from an approach based on main poles to a diffuse network, also in small and medium-sized cities. In the Italian case study, the National Strategy for Inland Areas (SNAI) represents a significant step to programming for the rationalization of mobility, health and education services. Moreover, as SNAI affirms, the recomposition of the system of services is preparatory to the vision of new economic and social growth; 
- $\quad$ valorize the possible relationships between cities and the contest, re-establishing functional connections through green and blue networks, which can provide a significant contribution to improving connectivity, the functionality of ecosystems but also the quality of life, through territorial regeneration of wider contexts;

- $\quad$ reinforce the network of sustainable mobility, with particular attention to pedestrian and cycle paths and their intersections with the system of transport networks, in interactions with green and blue networks that become structural elements of the city and the principal axes of connection with the local context;

- Finally, it is crucial to innovate instruments and decision-making processes of the city and the territory and rethink the emergency and risk management into ordinary planning, favoring the fruitful interaction among different and complementary expertise, like fluid dynamics and physics, together with architects and planners, to develop appropriate solutions to contrast the virus propagation. The gap between emergency management and the planning system is one of the primary limits to the adoption of a strategic preparedness approach [64-66]. A meaningful advance would be to establish a close relationship between preventive and ordinary planning through the new concept and practice of risk-sensitive planning and to foster the participation of community stakeholders in decision making through a close interaction between communities, scientists and government representatives [67]. As mentioned above, it is crucial to increase awareness to better control and orient people's behaviors and actions to prevent the spread of the virus effectively.

\section{Conclusions}

We have seen that the spread of the virus has not been indifferent to the morphological, climatic and pollution conditions in cities or parts of them. In particular, the profound relationship between the spread of the virus and pollution forces the acceleration of the transition towards sustainability, particularly in urban areas. It is clear that we are facing a situation of "Post Disaster Window of Opportunity," so that from the current crisis, new scenarios of urban and territorial planning could develop, finally real-oriented towards overall sustainability transition of territorial transformation actions. It is necessary to rethink and reshape the organization of the living environment of cities, making use of the network of open spaces and greenery as a leverage to increase preparedness for health crises of this type, which may happen again in the future. Furthermore, a transition to sustainability is increasingly urgent to rethink the city, not as an island to concentrate all services and functions but, from a polycentric perspective, to reconsider cities and most populated areas in close relation with the territorial contexts and, therefore, with the network of small cities of inland areas.

Author Contributions: M.S. conceived the presented idea and supervised the findings of this work. M.P. and I.P. investigated and performed the qualitative review. All authors discussed the results and contributed to the final manuscript. All authors have read and agreed to the published version of the manuscript.

Funding: This research was funded by the Italian Ministry of Foreign Affairs and International Cooperation: Research Project RE-LAND (Resilient Landscape) Great Relevance project Italy-USA Science and Technology Cooperation.

Conflicts of Interest: The authors declare no conflict of interest.

\section{References}

1. Xu, J.; Zhao, S.; Teng, T.; Abdalla, A.E.; Zhu, W.; Xie, L.; Wang, Y.; Guo, X. Systematic comparison of two animal-to-human transmitted human coronaviruses: SARS-CoV-2 and SARS-CoV. Viruses 2020, 12. [CrossRef] [PubMed]

2. United Nations. Presented at the United Nations Conference on the Human Environment (Stockholm Conference), Stockholm, Sweden, 5-16 June 1972. 
3. IUCN. World Conservation Strategy Living Resource Conservation for Sustainable Development; IUCN-UNEP-WWF: Gland, Switzerland, 1980.

4. United Nations. Brundtland Report. 1987. Available online: https://www.are.admin.ch/are/en/home/ sustainable-development/international-cooperation/2030agenda/un-_-milestones-in-sustainable-development/ 1987--brundtland-report.html (accessed on 1 May 2020).

5. UNCED. Earth Summit: Sustainable Development Knowledge Platform. Available online: https:// sustainabledevelopment.un.org/milestones/unced (accessed on 1 May 2020).

6. United Nations. Department of Economic and Social Affairs (UNDESA): THE 17 GOALS|Department of Economic and Social Affairs. Available online: https://sdgs.un.org/goals (accessed on 1 May 2020).

7. Coronavirus. Boeri: “Via Dalle Città, Nei Vecchi Borghi C'è Il Nostro Futuro"|Rep. Available online: https://rep.repubblica.it/pwa/intervista/2020/04/20/news/coronavirus_boeri_via_dalle_citta_nei_vecchi_borghi_ c_e_il_nostro_futuro2-254557453/ (accessed on 1 April 2020).

8. Bourouiba, L. Turbulent Gas Clouds and Respiratory Pathogen Emissions: Potential Implications for Reducing Transmission of COVID-19. JAMA 2020. [CrossRef] [PubMed]

9. Flügge, C. Über die nächsten Aufgaben zur Erforschung der Verbreitungsweise der Phthise. DMW 1897, 23, 665-668. [CrossRef]

10. Wells, W.F. On air-borne infection: Study II. Droplets and droplet nuclei. Am. J. Epidemiol. 1934, 20, 611-618. [CrossRef]

11. DUGUID, J.P. The numbers and the sites of origin of the droplets expelled during expiratory activities. Edinb. Med. J. 1945, 52, 385-401.

12. Loudon, R.G.; Roberts, R.M. Droplet expulsion from the respiratory tract. Am. Rev. Respir. Dis. 1967, 95, 435-442. [CrossRef]

13. Fennelly, K.P.; Martyny, J.W.; Fulton, K.E.; Orme, I.M.; Cave, D.M.; Heifets, L.B. Cough-generated Aerosols of Mycobacterium tuberculosis: A New Method to Study Infectiousness. Am. J. Respir. Crit. Care Med. 2004, 169, 604-609. [CrossRef]

14. Barker, J.; Stevens, D.; Bloomfield, S.F. Spread and prevention of some common viral infections in community facilities and domestic homes. J. Appl. Microbiol. 2001, 91, 7-21. [CrossRef]

15. Lewis, D. Is the coronavirus airborne? Experts can't agree. Nature 2020, 580, 175. [CrossRef]

16. Bourouiba, L.; Dehandschoewercker, E.; Bush, J.W.M. Violent expiratory events: On coughing and sneezing. J. Fluid Mech. 2014, 745, 537-563. [CrossRef]

17. Yu, I.T.S.; Li, Y.; Wong, T.W.; Tam, W.; Chan, A.T.; Lee, J.H.W.; Leung, D.Y.C.; Ho, T. Evidence of Airborne Transmission of the Severe Acute Respiratory Syndrome Virus. N. Engl. J. Med. 2004, 350, 1731-1739. [CrossRef] [PubMed]

18. Liu, Y.Y.; Ning, Z.; Chen, Y.; Guo, M.; Liu, Y.Y.; Gali, N.K.; Sun, L.; Duan, Y.; Cai, J.; Westerdahl, D.; et al. Aerodynamic Characteristics and RNA Concentration of SARS-CoV-2 Aerosol in Wuhan Hospitals during COVID-19 Outbreak. bioRxiv 2020. [CrossRef]

19. Qian, H.; Miao, T.; LIU, L.; Zheng, X.; Luo, D.; Li, Y. Indoor transmission of SARS-CoV-2. medRxiv 2020. [CrossRef]

20. Setti, L.; Passarini, F.; De Gennaro, G.; Barbieri, P.; Perrone, M.G.; Borelli, M.; Palmisani, J.; Di Gilio, A.; Torboli, V.; Fontana, F.; et al. SARS-Cov-2RNA Found on Particulate Matter of Bergamo in Northern Italy: First Evidence. Environ. Res. 2020, 109754. [CrossRef] [PubMed]

21. Fattorini, D.; Regoli, F. Role of the chronic air pollution levels in the Covid-19 outbreak risk in Italy. Environ. Pollut. 2020, 264, 114732. [CrossRef]

22. COVID-19. How Cities around the World Are Coping|World Economic Forum. Available online: https: //www.weforum.org/agenda/2020/03/how-should-cities-prepare-for-coronavirus-pandemics/ (accessed on 1 May 2020).

23. Prevent Epidemics|How Prepared is Your Country for the Next Epidemic. Available online: https:// preventepidemics.org/ (accessed on 1 May 2020).

24. Smolinski, M.S.; Hamburg, M.A.; Lederberg, J. Microbial Threats to Health; National Academies Press: Washington, DC, USA, 2003.

25. Bonds, M.H.; Dobson, A.P.; Keenan, D.C. Disease Ecology, Biodiversity, and the Latitudinal Gradient in Income. PLoS Biol. 2012, 10. [CrossRef] 
26. Jones, K.E.; Patel, N.G.; Levy, M.A.; Storeygard, A.; Balk, D.; Gittleman, J.L.; Daszak, P. Global trends in emerging infectious diseases. Nature 2008, 451,990-993. [CrossRef]

27. Daszak, P. Anatomy of a pandemic. Lancet 2012, 380, 1883-1884. [CrossRef]

28. Capolongo, S.; Rebecchi, A.; Dettori, M.; Appolloni, L.; Azara, A.; Buffoli, M.; Capasso, L.; Casuccio, A.; Oliveri Conti, G.; D'Amico, A.; et al. Healthy Design and Urban Planning Strategies, Actions, and Policy to Achieve Salutogenic Cities. Int. J. Environ. Res. Public Health 2018, 15, 2698. [CrossRef]

29. World Health Organization. Health as the Pulse of the New Urban Agenda. Available online: https: //www.who.int/phe/publications/urban-health/en/ (accessed on 1 May 2020).

30. WHO. Why Urban Health Matters; WHO: Geneva, Switzerland, 2010.

31. Alirol, E.; Getaz, L.; Stoll, B.; Chappuis, F.; Loutan, L. Urbanisation and infectious diseases in a globalised world. Lancet Infect. Dis. 2011, 11, 131-141. [CrossRef]

32. Ferrari, A.; Santus, E.; Cirillo, D.; Ponce-de-Leon, M.; Marino, N.; Ferretti, M.T.; Chadha, A.S.; Mavridis, N.; Valencia, A. Reproducing SARS-CoV-2 epidemics by region-specific variables and modeling contact tracing App containment. medRxiv 2020. [CrossRef]

33. Wolf, M. Rethinking Urban Epidemiology: Natures, Networks and Materialities. Int. J. Urban Reg. Res. 2016, 40, 958-982. [CrossRef] [PubMed]

34. Connolly, C.; Keil, R.; Ali, S.H. Extended urbanisation and the spatialities of infectious disease: Demographic change, infrastructure and governance. Urban Stud. 2020. [CrossRef]

35. Cliff, A.D.; Andrew, D.; Haggett, P.; Smallman-Raynor, M. World Atlas of Epidemic Diseases; Arnold: London, UK, 2004.

36. Bourdin, S.; Jeanne, L.; Nadou, F.; Noiret, G. Does Lockdown Work? A Spatial Analysis of the Spread and Concentration of Covid-19 in Italy. Available online: https://www.researchgate.net/publication/340979183_ Does_lockdown_work_A_spatial_analysis_of_the_spread_and_concentration_of_Covid-19_in_Italy (accessed on 1 May 2020).

37. Parnell, S.; Oldfield, S. The Routledge Handbook on Cities of the Global South; Routledge: Abington, UK, 2014.

38. Report of the WHO-China Joint Mission on Coronavirus Disease 2019 (COVID-19). Available online: https://www. who.int/publications/i/item/report-of-the-who-china-joint-mission-on-coronavirus-disease-2019-(covid-19) (accessed on 1 April 2020).

39. Ali, S.H.; Keil, R. Contagious Cities. Geogr. Compass 2007, 1, 1207-1226. [CrossRef]

40. Coker, R.J.; Hunter, B.M.; Rudge, J.W.; Liverani, M.; Hanvoravongchai, P. Emerging infectious diseases in southeast Asia: Regional challenges to control. Lancet 2011, 377, 599-609. [CrossRef]

41. Cities and COVID19: Preparing for Pandemics|ORF. Available online: https://www.orfonline.org/expertspeak/cities-and-covid-19-preparing-for-pandemics-67017/ (accessed on 1 June 2020).

42. Urban Density Is Not an Enemy in the Coronavirus Fight: Evidence from China. Available online: https://blogs. worldbank.org/sustainablecities/urban-density-not-enemy-coronavirus-fight-evidence-china (accessed on 1 May 2020).

43. World Bank. World Development Report 2009. 2009. Available online: https://openknowledge.worldbank. org/handle/10986/5991 (accessed on 1 May 2020).

44. Virus Outbreak Disrupts Global Car Makers in China-WSJ. Available online: https://www.wsj.com/articles/ virus-outbreak-disrupts-global-car-makers-in-china-11580232158 (accessed on 1 May 2020).

45. Will COVID-19 Make Us Think of Cities Differently?-NewCities. Available online: https://newcities.org/ the-big-picture-will-covid-19-make-us-think-cities-differently/ (accessed on 1 May 2020).

46. Outbreaks Like Coronavirus Start in and Spread from the Edges of Cities. Available online: https: //theconversation.com/outbreaks-like-coronavirus-start-in-and-spread-from-the-edges-of-cities-130666 (accessed on 1 May 2020).

47. Barca, F. Towards a Territorial Social Agenda for the European. Union 1 Report Working Paper; Ministry of Economy and Finance: Roma, Italy, 2009.

48. DPS. Accordo di Partenariato 2014-2020; Department for Development and Economic Cohesion, Presidenza del Consiglio dei Ministri: Rome, Italy, 2014.

49. The Pandemic Isn't a Black Swan but a Portent of a More Fragile Global System|The New Yorker. Available online: https://www.newyorker.com/news/daily-comment/the-pandemic-isnt-a-black-swan-but-aportent-of-a-more-fragile-global-system (accessed on 1 April 2020).

50. Sargolini, M. Urban Landscapes: Environmental Networks and Quality of Life; Springer: Mailand, Italy, 2013. 
51. The Spoils of the Park: With a Few Leaves from the Deep-laden Note-books of-Frederick Law Olmsted-Google Libri. Available online: https://books.google.it/books/about/The_Spoils_of_the_Park.html? $\mathrm{id}=\_$K3xnUI1BHwC\&redir_esc=y (accessed on 1 May 2020).

52. Grifoni, R.C.; D’Onofrio, R.; Sargolini, M.; Pierantozzi, M.; Cocci Grifoni, R.; D'Onofrio, R.; Sargolini, M.; Pierantozzi, M. A Parametric Optimization Approach to Mitigating the Urban Heat Island Effect: A Case Study in Ancona, Italy. Sustainability 2016, 8, 896. [CrossRef]

53. Sargolini, M. Environmental Management For Biodiversity Conservation. In Nature Conservation; Springer: Berlin/Heidelberg, Germany, 2007; pp. 358-368.

54. Jacobs, J. The Economy of Cities; Random House: New York, NY, USA, 1969.

55. Jacobs, J. Cities and the Wealth of Nations: Principles of Economic Life; Random House: New York, NY, USA, 1984.

56. Becker, S.L.; Reusser, D.E. Disasters as opportunities for social change: Using the multi-level perspective to consider the barriers to disaster-related transitions. Int. J. Disaster Risk Reduct. 2016, 18, 75-88. [CrossRef]

57. Bendimerad, F. Disaster Risk Reduction and Sustainable Development. Correlation Between Disasters and Development Impact of Disasters on Development. 2005. Available online: https:/pdfs.semanticscholar.org/ 7219/29932392f6b5d9bd4861f615d8554dade5e1.pdf (accessed on 1 May 2020).

58. Wisner, B.; Blaikie, P.; Cannon, T.; Davis, I. At Risk: Natural Hazards, Peoples Vulnerability and Disasters. Taylor and Francis; Routledge: Abington, UK, 2014.

59. Brundiers, K.; Eakin, H. Leveraging Post-Disaster Windows of Opportunities for Change towards Sustainability: A Framework. Sustainability 2018, 10, 1390. [CrossRef]

60. Birkmann, J.; Buckle, P.; Jaeger, J.; Pelling, M.; Setiadi, N.; Garschagen, M.; Fernando, N.; Kropp, J. Extreme events and disasters: A window of opportunity for change? Analysis of organizational, institutional and political changes, formal and informal responses after mega-disasters. Nat. Hazards. 2010, 55, 637-655. [CrossRef]

61. Rees, W.; Wackernagel, M. Urban ecological footprints: Why cities cannot be sustainable-And why they are a key to sustainability. Environ. Impact Assess. Rev. 1996, 16, 223-248. [CrossRef]

62. Wackernage, M.; Rees, W.E. Perceptual and structural barriers to investing in natural capital: Economics from an ecological footprint perspective. Ecol. Econ. 1997, 20, 3-24. [CrossRef]

63. Landi, D. The Image of the Hyper City. Int. J. Semiot. Law. 2019, 32, 533-548. [CrossRef]

64. Sendai Framework for Disaster Risk Reduction 2015-2030|UNDRR. Available online: https://www.undrr.org/ publication/sendai-framework-disaster-risk-reduction-2015-2030 (accessed on 1 May 2020).

65. Greiving, S.; Fleischhauer, M.; Wanczura, S. Management of natural hazards in Europe: The role of spatial planning in selected EU member states. J. Environ. Plan. Manag. 2006, 49, 739-757. [CrossRef]

66. Incheon Declaration and Framework for Action. Available online: https://iite.unesco.org/publications/ education-2030-incheon-declaration-framework-action-towards-inclusive-equitable-quality-educationlifelong-learning/ (accessed on 1 May 2020).

67. Sargolini, M. Il ruolo dei piani di emergenza nelle politiche urbane. In Il Piano Dell'emergenza Nell'uso E Nella Gestione Del Territorio; Franco Angeli: Milan, Italy, 2020.

(C) 2020 by the authors. Licensee MDPI, Basel, Switzerland. This article is an open access article distributed under the terms and conditions of the Creative Commons Attribution (CC BY) license (http://creativecommons.org/licenses/by/4.0/). 